\title{
The effects of the frog Eleutherodactylus coqui on invertebrates and ecosystem processes at two scales in the Luquillo Experimental Forest, Puerto Rico
}

\author{
Karen H. Beard*1 ${ }^{*}$ Anne K. Eschtruth*, Kristiina A. Vogt ${ }^{\dagger}$, Daniel J. Vogt ${ }^{\dagger}$ and \\ Frederick N. Scatena ${ }^{\ddagger}$
}

*School of Forestry and Environmental Studies, Yale University, New Haven, CT 06511, USA

†College of Forest Resources, University of Washington, Seattle, WA 98195, USA

fInternational Institute of Tropical Forestry, USDA Forest Service, Rio Piedras, Puerto Rico 00928, USA

(Accepted 2 November 2002)

\begin{abstract}
Determining the ubiquity of top-down control effects of predators on their prey and ecosystem processes is important for understanding community and ecosystem-level consequences that may result from predator loss. We conducted experiments at two spatial scales to investigate the effects of terrestrial frogs (Eleutherodactylus coqui) on aerial and litter invertebrates, plant growth and herbivory, and litter decomposition. At both scales, frogs reduced aerial invertebrates and leaf herbivory, but had no effect on litter invertebrates. At the smaller scale, frogs increased foliage production rates, measured as the number of new leaves and new leaf area produced, by $80 \%$ and decomposition rates by $20 \%$. The influence of $E$. coqui on increasing primary productivity and decomposition rates at the smaller scale appeared to be a result of elimination and excretion rather than of controlling prey. While the results provide evidence for frogs controlling herbivorous prey at both scales, species effects on ecosystem processes were only detectable at the smaller scale. The results highlight the difficulties in conducting experiments at large spatial scales. The findings from this study imply that the loss of amphibians and other species of higher trophic levels may affect nutrient cycling rates in tropical forests.
\end{abstract}

Key Words: decomposition, enclosures, herbivory, productivity, scaling, subtropical wet forests, top-down control, trophic cascades

\section{INTRODUCTION}

Establishing the existence of top-down effects is fundamental to understanding the potential consequences of predator loss (Terborgh 1988). To determine whether predator loss has consequences on communities and ecosystems in terrestrial systems, it should be determined whether the predator has direct effects on their prey and indirect effects on ecosystem processes, such as primary production and decomposition of leaf litter. A number of studies have shown that predators indirectly influence herbivores and plant production rates (for a review see Schmitz et al. 2000). For example, spiders (Carter \& Rypstra 1995), mantids (Moran \& Hurd 1998), and birds (Strong et al. 2000) have been shown to control herbivorous insects and influence primary producer performance. In contrast to the many studies of predator impacts on plant production, fewer studies have examined the effects

\footnotetext{
${ }^{1}$ Corresponding author, at Department of Forest, Range and Wildlife Sciences and Ecology Center, Utah State University, Logan, UT 843225230, USA. Email: karen.beard@usu.edu
}

of predators on leaf-litter prey and decomposition rates. Results from some studies have found increased decomposition rates when mites predated on bacterial- and fungal-feeding nematodes (Laakso \& Setala 1999) and salamanders predated on litter invertebrates (Wyman 1998).

These types of top-down-controlled trophic cascades at one time were thought to only occur in simple ecosystems; however, recent studies have revealed that they also occur in highly diverse terrestrial ecosystems (Dial \& Roughgarden 1995, Letourneau \& Dyer 1998, Terborgh et al. 2001). Therefore, predator losses in diverse, tropical ecosystems may result in community and ecosystem consequences. This is of concern because predators, for example, amphibians, appear to be declining in many parts of the tropical world (Blaustein \& Kiesecker 2002, Lips 1998, Stallard 2001). Although research has been conducted to document the causes and extent of amphibian loss (Davidson et al. 2001, Pounds \& Crump 1994, Woolbright 1997), few studies have examined how changes in their population levels might influence the 
systems that they inhabit (Wyman 1998). The research reported in this paper examined whether a terrestrial frog, Eleutherodactylus coqui (Thomas), has cascading effects on its prey, plant productivity and nutrient availability in a neotropical forested ecosystem in Puerto Rico.

Eleutherodactylus coqui is the most abundant nocturnal vertebrate in the study forest and has densities that are among the highest known for any amphibian in the world (around 20000 individuals $\mathrm{ha}^{-1}$ ) (Stewart \& Woolbright 1996). Eleutherodactylus coqui is a generalist predator and consumes an estimated 114000 prey items ha ${ }^{-1}$ per night (Stewart \& Woolbright 1996). Anecdotal data suggest that $E$. coqui control their prey since there are high insectivore densities and low herbivory rates in the study forest (Angulo-Sandoval \& Aide 2000). We hypothesized that the direct feeding interaction of E. coqui creates trophic cascades that influence two ecosystem processes. We predicted that $E$. coqui has cascading effects on increasing plant growth rates by reducing herbivore populations and herbivory rates. We also predicted that $E$. coqui has cascading effects on the decay rates of leaf litter either (1) by reducing predatory leaf-litter invertebrate populations, which may release decomposer organisms, and subsequently increase leaf-litter decomposition rates, or (2) by increasing the turnover rates of their prey, which may increase the availability of nutrients that limit decomposer organisms in the study system, and thereby increase leaf-litter decomposition rates (Bloomfield et al. 1993).

We were interested to determine if the findings would be consistent at different scales. Since processes in nature are sensitive to spatial scale, we assumed some processes might be observable at one scale and not at another (e.g. Gross et al. 2000, Stohlgren et al. 1999). We tested our predictions at a small scale $\left(1 \mathrm{~m}^{3}\right)$ typical of many ecological studies (Kareiva \& Anderson 1988) where driving variables could be well monitored and the scale at which the pivotal feedback for an ecosystem function such as decomposition should be detectable. We also tested our predictions at a larger scale $(20 \times 20 \mathrm{~m})$ where we thought driving variables could not be as easily monitored. However, the larger scale is more representative of the scale to which the vegetative community responds and, therefore, an understanding of the effects of the frog at this scale was deemed important. This research provides direct tests of the hypotheses that predators in diverse systems have top-down control effects on multiple ecosystem processes and that these effects differ with spatial scale.

\section{METHODS}

\section{Study site}

The research sites were located in the Luquillo Experimental Forest (LEF) in the north-eastern corner of Puerto Rico $\left(18^{\circ} 18^{\prime} \mathrm{N}, 65^{\circ} 50^{\prime} \mathrm{W}\right)$. The forest is classified as sub- tropical wet (Ewel \& Whitmore 1973). Peak precipitation occurs between May and November, with average inputs of $\sim 400 \mathrm{~mm} \mathrm{mo}^{-1}$ during these months and drier periods between January and April when precipitation inputs average 200-250 mm mo ${ }^{-1}$ (Garcia-Martino et al. 1996). Mean monthly air temperatures are fairly constant throughout the year and average between $21-24{ }^{\circ} \mathrm{C}$ (Garcia-Martino et al. 1996).

The study sites were located in the mature secondary tabonuco forest zone that is dominated by Dacryodes excelsa Vahl (tabonuco), Prestoea montana (Graham) G. Nicholson, Manilkara bidentata (A.DC.) A. Chev., Sloanea berteriana Choisy ex DC., and Cecropia schreberiana Miq. The understorey is dominated by Danaea nodosa (L.) Sm., Ichnanthus palens (Sw.) Munro ex Benth., Heliconia caribaea Lam., Piper glabrescens (Miq.) C.DC., and Scleria canescens Boeck. Both experiments were conducted in the Bisley Experimental Watershed area. All study sites were located at elevations between 250 and $300 \mathrm{~m}$ and had similar exposure to sunlight and topography.

\section{Experimental design}

The small-scale experiment was conducted for 4 mo from 15 June to 14 October 1999 . Twenty $\left(1 \mathrm{~m}^{3}\right)$ field enclosures were constructed using a frame of PVC tubing covered by plastic mesh material with $0.95 \times 0.95-\mathrm{cm}$ mesh size, including the bottom of the cages. This mesh size was chosen because it was large enough to allow free movement of most invertebrates into and out of the enclosures but small enough to prevent the movement of adult frogs. Juvenile frogs could enter through this mesh size.

All enclosures were placed directly on the surface of the forest floor in 10 pairs in a $30 \times 35-\mathrm{m}$ area. There was at least $2 \mathrm{~m}$ between each pair of enclosures. One enclosure in each pair contained no frogs and the other contained frogs at a high estimate of natural densities (7 individuals $\mathrm{m}^{-2}$ ). This density was determined using the maximum estimate for adults of $1.14 \mathrm{~m}^{-2}$ prior to Hurricane Hugo passing through the island of Puerto Rico in 1989 (Stewart \& Woolbright 1996) and the reported 6-fold increase in the adult population density after the hurricane (Woolbright 1996).

The large-scale experiment was conducted for 6 mo from 20 June 1999 to 19 December 1999 using a complete, randomized block design consisting of three blocks of three treatments. There was at least $500 \mathrm{~m}$ between each block and at least $30 \mathrm{~m}$ between each treatment. Each treatment consisted of a $20 \times 20$-m plot within the closed-canopy forest. The treatments included exclosures to experimentally eliminate E. coqui and two sets of controls (exclosure controls and natural controls).

Each exclosure for both the removal treatment and 
exclosure control plots was constructed using mesh material that had a mesh size of $0.95 \times 0.95 \mathrm{~cm}$. Exclosure walls extended from $30 \mathrm{~cm}$ below to $3 \mathrm{~m}$ above the soil surface. No mesh was added to the 'tops' of the exclosures because canopy trees were included in the plots. Most animals, such as birds and lizards, could freely enter and leave the removal and exclosure control plots perhaps with the exception of introduced ground mammals, such as mongooses and rats, which were not observed to enter the removal and exclosure control plots as freely as they could enter unmanipulated areas. To determine if the presence of the fences was significantly altering the exclosure control plots, natural control plots were created, where E. coqui populations were not manipulated and exclosure fences were not erected.

Eleutherodactylus coqui were transferred out of the removal plots during all 6 mo of the experiment, from 20 June to 19 December 1999. Removals were conducted approximately seven times monthly for 3 personhours and for a total collection time of $124 \mathrm{~h}$ in each removal plot over the $6 \mathrm{mo}$. Frogs were removed between 20h00-24h00 to coincide with their period of highest activity. Removed frogs were released in other parts of the forest at a distance of at least $100 \mathrm{~m}$ from plots to avoid homing (Gonser \& Woolbright 1995). Researchers conducting the removals, by walking in the plots looking for and removing frogs, created a disturbance in the removal plots. Because we were concerned that this disturbance may influence the results, the exclosure control plots were subjected to the same amount of human disturbance as the removal plots (i.e. researchers walked in exclosure control plots for time periods equal to that in the removal plots).

Starting in May 1999, male calling activity was used to determine removal effectiveness (Woolbright 1991). Male calling activity was measured as mean sound pressure levels between 20h00-22h00 on a biweekly basis using a Realistic Sound Pressure Level meter (Cat. No. 33-2055). In addition, a frog and lizard census was conducted in October 1999 between 20h00-24h00 in the plots. For 2 h, three people surveyed a plot by walking slowly side-byside through the plot. Frogs and lizards were located by inspecting soil, rocks, leaf litter and vegetation up to a height of $2 \mathrm{~m}$.

\section{Invertebrate community changes}

To measure changes in the aerial invertebrates in the small-scale experiment, one sticky trap $(10 \times 15 \mathrm{~cm}$ in area) was suspended in the top centre of each enclosure. Traps were replaced every $2 \mathrm{wk}$. In the large-scale experiment, invertebrate populations were sampled at monthly intervals from May to December 1999. Invertebrates were sampled over a 24-h period using a Malaise trap. If frogs or lizards were found in the dry collector, these sample collections were not used in the analysis. Invertebrates were counted, identified to taxonomic, and their lengths were measured and grouped into four size categories (<1 mm, 1-2 mm, 2-4 mm, or $>4 \mathrm{~mm}$ ). Order and size categories roughly approximate functional groups of the aerial invertebrates collected in the study site (Schowalter \& Ganio 1999).

To measure changes in leaf-litter invertebrates in the small-scale experiment, a mesh bag $(10 \times 20 \mathrm{~cm}$ in area with $0.95 \times 0.95-\mathrm{cm}$ mesh) filled with $100 \mathrm{~g}$ of mixed, air-dried, leaf litter from the forest floor was introduced into each enclosure. At the termination of the experiment (after $4 \mathrm{mo}$ ), the mesh bags were retrieved. In the largescale experiment, invertebrates were sampled at monthly intervals from May to December 1999 from litter collected from randomly selected $0.5 \times 0.5-\mathrm{m}$ areas of the forest floor in each plot. Invertebrates were extracted from the litter from both experiments using Tullgren funnels.

Litter invertebrates were identified and placed into guilds that best represented their feeding roles (Garrison \& Willig 1996, Goldwasser \& Roughgardner 1993, Pfeiffer 1996a, b). Feeding guilds roughly approximate functional groups of the litter invertebrates collected in the study site (Schowalter \& Ganio 1999). Feeding guilds included detrital feeders (Acarina, Blattodea, Coleoptera, Collembola, Dermaptera, Diplopoda, Isopoda, Isoptera), plant feeders (Hemiptera, Homoptera, Lepidoptera) and predators (Araneae, Chilopoda, Diptera, Hymenoptera, Pseudoscorpionida).

\section{Herbivory and plant growth}

To measure changes in herbivory and plant growth rates in the experiments, individual Piper glabrescens (Piperaceae) plants and Manilkara bidentata (Sapotaceae) seedlings were grown in $18-\mathrm{cm}$-diameter pots. A total of eight pots were transferred into each enclosure (four pots with Piper and four with Manilkara). Each large-scale exclosure received 30 pots of Piper and 30 pots of Manilkara that were randomly located within the plot. Plants used in the experiments were excavated from the forest immediately surrounding the study area. Plants were allowed to acclimate in the pots for several weeks at the field sites prior to their placement into the experimental systems. Plants were randomly selected for placement into enclosures and plots.

At the beginning and end of the experiments, the following measurements were recorded for each plant: stem height, number of leaves, total leaf area and herbivory (leaf area missing due to herbivory) for all leaves on each plant. Leaf area was determined and herbivory estimated as area lost on all leaves as a percentage of total leaf area $\left(\mathrm{cm}^{2} \mathrm{~cm}^{-2}\right)$. Herbivory on new leaves (leaves developed during the experiment) was determined as the leaf area lost on new leaves as a percentage of new leaf area. At 
the end of the experiments, leaves and stems were processed and measured separately, and roots were carefully excavated from the soil. Plant tissues were dried to a constant weight at $70{ }^{\circ} \mathrm{C}$ and weighed.

In the large-scale experiment, differences in herbivory rates due to the treatments would be difficult to determine since the herbivory experienced by a given plant is often affected by the surrounding plant species composition (Callaway 1995). Therefore, in the large-scale experiment, herbivory rates were estimated by determining the ratio of herbivory on leaves of the potted plants measured at 6 mo compared to that measured at $3 \mathrm{mo}$; this reflects the amount of herbivory that occurred on plants in the second 3 mo-period of the experiment.

\section{Leaf-litter decomposition rates}

Leaf-litter decomposition rates were determined using litter decomposition bags (Swift et al. 1979). Mixed leaf litter was collected from forest floor near the study sites. Litter consisted primarily of leaves from Dacryodes excelsa, Sloanea berteriana, Cecropia schreberiana, Piper glabrescens, Manilkara bidentata, Psychotria berteriana DC., Palicourea riparia Benth., and Miconia spp. Approximately equal proportions by weight of the different species were used in the litterbags. Each litterbag contained $5 \mathrm{~g}$ of air-dried litter material and subsamples of air-dried leaves were separately processed after every fifth litterbag was constructed to develop an air-dried to oven-dried $\left(70{ }^{\circ} \mathrm{C}\right)$ conversion factor. Each experimental enclosure had two decomposition bags placed on the surface of the forest floor while 40 litterbags were placed in each of the plots.

In the small-scale experiment, litterbags were removed at the termination of the experiment. In the large-scale experiment, half the litterbags were removed after 3 mo and the other half after 6 mo. Each retrieved litterbag was cleaned of contaminating material and oven-dried at 70 ${ }^{\circ} \mathrm{C}$ to obtain a value for the dry weight remaining. Samples were ground with a $2-\mathrm{mm}$ mesh screen. A subsample from each was ashed overnight at $500{ }^{\circ} \mathrm{C}$ to develop an ash-free conversion factor to calculate weight losses on an ash-free basis.

\section{Statistical analyses}

All statistical analyses were conducted using SAS for Window v. 8 (SAS Institute, Cary, New York, USA). Paired t-tests for two independent samples were used to determine differences between the frog and frog-free enclosures in the small-scale experiment. In the largescale plot experiment, differences among the three treatments were determined using an analysis of variance controlling for block and a Duncan test for means comparisons. To determine differences between any two treatments, t-tests for paired means, where the three blocks were treated as replicates, were used. To determine if analyses between removal and exclosure control plots were 'real', retrospective power analyses were conducted using a two-sample unequal variance calculation. Power was set equal to 0.80 when required. All statistical analyses were tested for significance at the 0.05 level. In accordance with the Bonferroni-Dunn test, family-wise type I error rates of 0.05 were established for multiple comparisons. It was not deemed necessary to transform the data.

\section{RESULTS}

\section{Treatment effectiveness}

The small-scale enclosures were monitored weekly during the 4-mo experiment between 20h00-24h00. Juveniles were observed on two occasions and Anolis lizards on one occasion in enclosures, and were subsequently removed. No other vertebrates, other than the stocked E. coqui, were observed in the enclosures. There was a total of 10 frog carcasses found in the small enclosures that contained $E$. coqui. When mortality was observed in enclosures, carcasses were not removed, and frogs were replaced to keep frog density constant throughout the experiment. The number of other organisms that died in enclosures during the experiments was not determined.

From July to December 1999, a total of 3944 E. coqui, including 1513 adults, 2411 juveniles, and two eggclutches, were removed from the removal plots in the large-scale experiment. This removal rate translates into 98600 individuals $\mathrm{ha}^{-1}$ transferred from the removal plots suggesting a significant removal when compared with their calculated natural density of 20000 individuals ha ${ }^{-1}$. During the frog census conducted in October 1999, the number of adult frogs observed in removal plots was significantly lower than that observed in control plots $\left(\mathrm{F}_{2,6}=\right.$ 18.4, $\mathrm{P}=0.003)$. Even though juveniles were removed from removal plots, there was no difference in the number of juvenile frogs visually observed among the three treatments $\left(F_{2,6}=0.16, P=0.86\right)$. There was also no difference in the number of Anolis observed among the treatments $\left(\mathrm{F}_{2,6}=1.27, \mathrm{P}=0.35\right)$.

There was no difference in the average sound pressure among the treatments before the removals started $\left(\mathrm{F}_{2,6}=\right.$ $0.39, \mathrm{P}=0.69)$. After the removals started and over the course of the 6-mo experiment, the average sound pressure was consistently lower in the removal than in the control plots $\left(\mathrm{F}_{2,6}=5.24, \mathrm{P}=0.05\right)$. After the removals were initiated, there was no decibel difference between the exclosure and natural control plots $(\mathrm{df}=2, \mathrm{P}=0.62)$. 


\section{Aerial invertebrates}

In the small-scale experiment, the number of aerial invertebrates caught on sticky traps was greater in the enclosure controls than in enclosures with E. coqui (Figure 1). Diptera (76.1\% of the total individuals caught), Hymenoptera $(11.1 \%)$, Coleoptera $(4.3 \%)$ and Homoptera $(1.5 \%)$ constituted $93 \%$ of all individuals caught in the sticky traps in the enclosure controls. All individuals caught sorted into the following size classes: $<1 \mathrm{~mm}(10.8 \%)$, $1-2 \mathrm{~mm}$ (71.9\%), 2-4 mm (16.8\%), and > $4 \mathrm{~mm}(0.5 \%)$. In the enclosures with E. coqui, Diptera (74.5\%), Hymenoptera (12.8\%), Coleoptera (3.9\%) and Homoptera (2.4\%) constituted $94 \%$ of all individuals caught in the sticky traps. All individuals caught fell into the following size classes: < $1 \mathrm{~mm}$ (11.4\%), 1-2 mm (72.1\%), 2-4 mm $(15.9 \%)$, and $>4 \mathrm{~mm}(0.6 \%)$. There were no differences in the number of invertebrates in any taxon or size category between the treatments $(\mathrm{df}=9, \mathrm{P}>0.05)$.

In the large-scale experiment, there were no significant differences in the number of aerial invertebrates caught among the treatments $\left(\mathrm{F}_{2,6}=0.04, \mathrm{P}=0.96\right)$ and, accordingly, no difference in the number of aerial invertebrates caught in the removal and exclosure control plots (Figure 1). In the exclosure control plots, Diptera $(81.8 \%$ of the total individuals caught), Homoptera (6.8\%), Lepidoptera (5.8\%), Hymenoptera (4.6\%) and Coleoptera (0.7\%) constituted over $99 \%$ of all individuals caught in the Malaise traps. All individuals caught sorted into the following size classes: $<1 \mathrm{~mm}$ (47.9\%), 1-2 mm (34.4\%), 2-4 $\mathrm{mm}(9.7 \%)$ and $>4 \mathrm{~mm}$

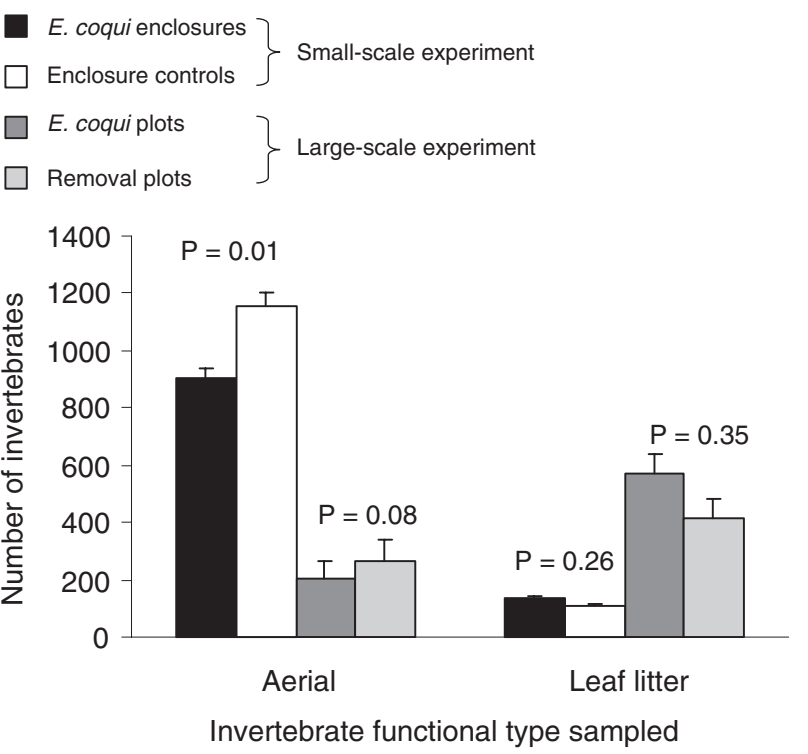

Figure 1. Mean total number of invertebrates $(+\mathrm{SE})$ in enclosures and plots with and without E. coqui in the Bisley Watersheds, Luquillo Experimental Forest, Puerto Rico. $n=10$ for the small-scale experiment and $\mathrm{n}=3$ for the large-scale experiment.
$(8.0 \%)$. In the removal plots, Diptera $(74.9 \%$ of the total individuals caught), Homoptera (10.6\%), Lepidoptera (7.5\%), Hymenoptera (2.7\%) and Coleoptera (1.0\%) constituted $97 \%$ of all individuals caught. All individuals caught fell into the following classes: $1 \mathrm{~mm}(52.1 \%), 1-$ $2 \mathrm{~mm}$ (26.8\%), 2-4 mm (12.9\%), and > $4 \mathrm{~mm}(8.2 \%)$. There were no differences among treatments in the number of invertebrates in any taxon or in any size category $\left(\mathrm{F}_{2,6}<5.14, \mathrm{P}>0.05\right)$.

\section{Leaf-litter invertebrates}

In the small-scale experiment, there was no difference in the total number of individual leaf litter invertebrates recorded in the enclosures and enclosure controls (Figure 1). There were no differences in invertebrate numbers in the three feeding guilds between the enclosures and enclosure controls (Figure 2). Acarina (38.7\%), Araneae (16.9\%), Hymenoptera (14.7\%), Diptera (6.5\%), Isopoda (4.6\%), Collembola (4.4\%), Diplopoda (3.5\%), Coleoptera $(2.4 \%)$ and Homoptera $(1.5 \%)$ constituted $93 \%$ of all individuals collected in leaf-litter samples in enclosure controls. Acarina (31.6\%), Araneae (19.0\%), Hymenoptera $(7.9 \%)$, Diptera $(8.0 \%)$, Isopoda $(8.8 \%)$, Collembola (6.9\%), Diplopoda (5.4\%), Coleoptera (3.0\%) and Homoptera $(2.7 \%)$ constituted $93 \%$ of all individuals collected in leaf-litter samples in the E. coqui enclosures. There were no differences in the number of invertebrates in any taxon between the treatments $(\mathrm{df}=9, \mathrm{P}>0.05)$.

In the large-scale experiment, there were no significant
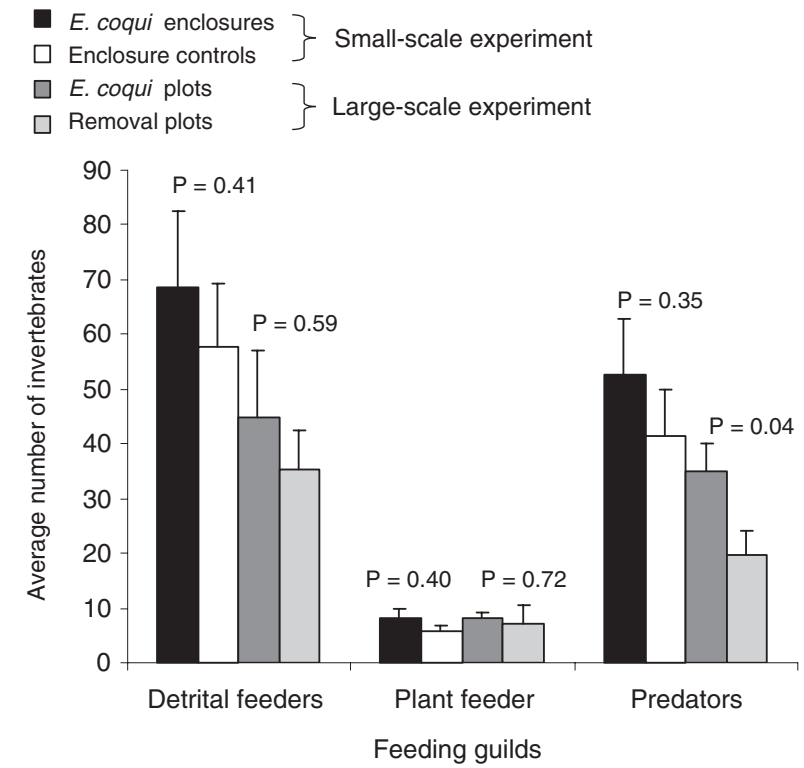

Figure 2. Mean number of leaf litter invertebrates $(+\mathrm{SE})$ in enclosures and plots with and without E. coqui in the Bisley Watersheds, Luquillo Experimental Forest, Puerto Rico. $\mathrm{n}=10$ for the small-scale experiment and $n=3$ for the large-scale experiment. 
differences in the total number of leaf-litter invertebrates or in the number of invertebrates in each feeding guild found among the treatments $\left(\mathrm{F}_{2,6}<5.14, \mathrm{P}>0.05\right)$. The total number of litter invertebrates recorded in removal plots was lower than that recorded in the exclosure control plots, but not significantly so (Figure 1). In the exclosure control plots, Acarina (34.6\%), Hymenoptera (26.5\%), Isoptera (19.0\%), Diplopoda (3.1\%), Diptera (2.6\%), Collembola (2.5\%), Isopoda (2.4\%), Coleoptera (2.0\%), Homoptera (1.2\%) and Araneae (1.6\%) constituted 96\% of all the individuals collected in the litter samples. In the removal plots, Acarina (38.5\%), Hymenoptera (18.9\%), Isoptera $(15.1 \%)$, Diplopoda $(6.1 \%)$, Diptera $(3.1 \%)$, Collembola (3.4\%), Isopoda (2.4\%), Coleoptera (2.3\%), Homoptera (1.4\%) and Araneae (1.4\%) constituted 93\% of all the individuals collected in the litter samples.

There were no differences between the exclosure control and natural control plots for the density of E. coqui, aerial invertebrates and litter invertebrates. Therefore, the fences were concluded to not significantly alter community composition. The exclosure control plots were thought to represent a more appropriate comparison of the presence and absence of $E$. coqui with the removal plots than the natural control plots because they both had human disturbance and fences. Therefore, the natural control plots are not considered further and only comparisons between the exclosure human and removal plots are presented.

\section{Herbivory loads}

Study plants used in the small- and large-scale experiments had a $99 \%$ survival. In the small-scale experiment, the per cent leaf area missing of Piper and Manilkara plants increased when E. coqui was absent (Figure 3a). The same patterns were observed when analysed using only new leaves ( $\mathrm{df}=9, \mathrm{P}=0.10,0.24$, respectively).

In the large-scale experiment, there was a significant increase in herbivory on new leaves in the removal plots between 3 and 6 mo for Piper compared with control plots (Figure 3b). A similar trend was found for Manilkara (Figure 3b). There were no significant differences for either Piper or Manilkara when all leaves, as opposed to only new leaves, were included in these analyses ( $\mathrm{df}=2$, $\mathrm{P}=0.90,0.63$, respectively).

\section{Plant growth}

In the small-scale experiment, the amount of both new Piper and Manilkara foliage produced in enclosures was greater than that produced in enclosure controls (Table 1). For Piper, three out of the five additional plant growth variables measured showed differences between treatments (Table 1). For Manilkara, two out of five additional
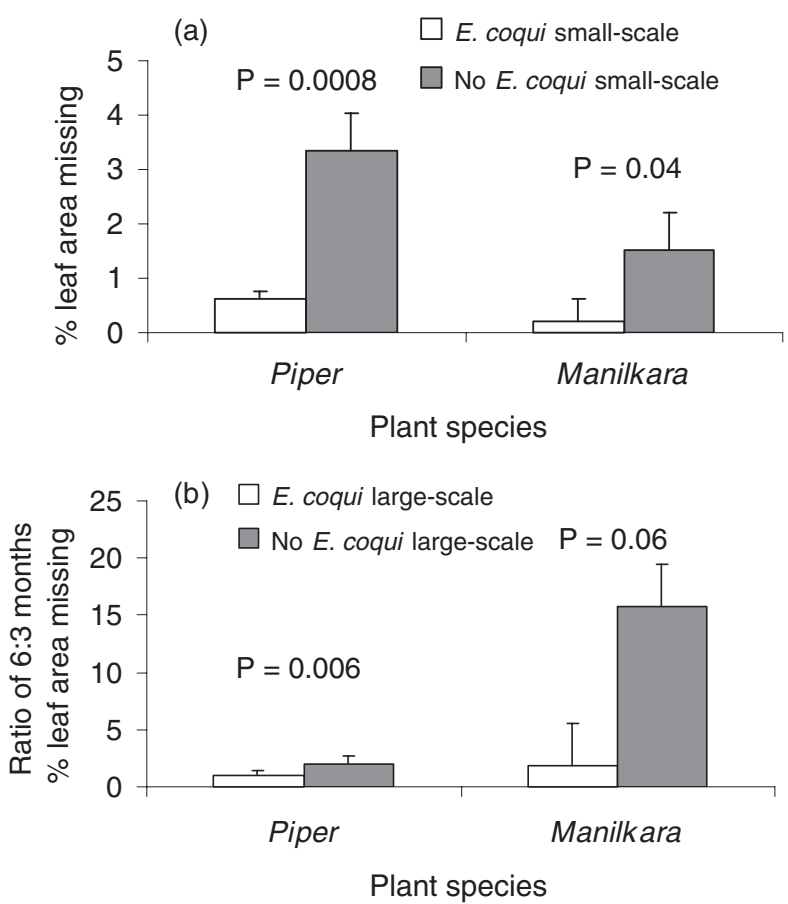

Figure 3. Herbivory measurements for plants (+ SE) grown in enclosures and plots with and without E. coqui in the Bisley Watersheds, Luquillo Experimental Forest, Puerto Rico. (a) Mean per cent leaf area missing after 4 mo for both Piper and Manilkara in the small-scale experiment. (b) Mean ratio of per cent leaf area missing from new leaves at 6 mo compared with that missing at 3 mo for both Piper and Manilkara in the large-scale experiment.

plant growth variables showed differences between treatments (Table 1).

For both plant species in the large-scale plots, stem height growth, the number of new leaves, the number of senesced leaves, leaf area, and above- and below-ground biomass were not significantly different between treatments at the termination of the experiment $(\mathrm{df}=2$, $\mathrm{P}>0.05$; Table 1).

\section{Leaf-litter decomposition rates}

In the small-scale experiment, leaf litter decomposed at a faster rate in enclosures with $E$. coqui than in enclosure controls (Figure 4). In the large-scale experiment, decomposition rates of mixed leaf litter did not differ by treatment after 3 or 6 mo (Figure 4).

\section{DISCUSSION}

\section{Effects on prey and ecosystem processes}

The results support the hypothesis that an amphibian can have top-down-control effects on prey dynamics, plant performance and leaf-litter decomposition rates. The first prediction, that $E$. coqui has top-down predator effects on 
Table 1. Mean values ( $\pm \mathrm{SE}$ ) for variables describing plant growth over 4 mo in $101-\mathrm{m}^{3}$ enclosures with and without $E$. coqui in the Bisley Watersheds, Luquillo Experimental Forest, Puerto Rico.

\begin{tabular}{|c|c|c|c|c|}
\hline \multirow[t]{2}{*}{ Measured variable (units) } & \multicolumn{2}{|c|}{ Piper $^{1}$} & \multicolumn{2}{|c|}{ Manilkara $^{1}$} \\
\hline & E. coqui & No E. coqui & E. coqui & No E. coqui \\
\hline \multicolumn{5}{|l|}{ Small-scale experiment } \\
\hline Leaf area increases $\left(\mathrm{cm}^{2}\right)$ & $171 \pm 16.6^{a}$ & $90.3 \pm 16.3^{\mathrm{b} *}$ & $8.72 \pm 0.97^{\mathrm{a}}$ & $4.75 \pm 1.27^{\mathrm{b}}$ \\
\hline Number of new leaves & $2.60 \pm 0.22^{\mathrm{a}}$ & $1.35 \pm 0.17^{\mathrm{b} *}$ & $0.75 \pm 0.13^{\mathrm{a}}$ & $0.45 \pm 0.10^{\mathrm{a}}$ \\
\hline Number of senesced leaves & $0.03 \pm 0.03^{\mathrm{a}}$ & $0.25 \pm 0.11^{\mathrm{a}}$ & $0.05 \pm 0.03^{\mathrm{a}}$ & $0.28 \pm 0.10^{\mathrm{b}}$ \\
\hline Stem height change $(\mathrm{cm})$ & $10.7 \pm 0.68^{a}$ & $6.77 \pm 1.13^{\mathrm{b}}$ & $0.74 \pm 0.15^{\mathrm{a}}$ & $1.81 \pm 0.16^{\mathrm{b} *}$ \\
\hline Above-ground biomass (g) & $1.61 \pm 0.08^{\mathrm{a}}$ & $1.32 \pm 0.08^{b}$ & $0.41 \pm 0.02^{\mathrm{a}}$ & $0.47 \pm 0.06^{\mathrm{a}}$ \\
\hline Below-ground biomass (g) & $1.03 \pm 0.07^{\mathrm{a}}$ & $0.89 \pm 0.09^{\mathrm{a}}$ & $0.16 \pm 0.02^{\mathrm{a}}$ & $0.21 \pm 0.04^{\mathrm{a}}$ \\
\hline \multicolumn{5}{|l|}{ Large-scale experiment } \\
\hline Leaf area increases $\left(\mathrm{cm}^{2}\right)$ & $56.6 \pm 30.5^{\mathrm{a}}$ & $65.4 \pm 46.0^{\mathrm{a}}$ & $5.10 \pm 2.35^{\mathrm{a}}$ & $7.67 \pm 2.60^{\mathrm{a}}$ \\
\hline Number of new leaves & $1.88 \pm 0.43^{\mathrm{a}}$ & $1.52 \pm 0.14^{\mathrm{a}}$ & $1.05 \pm 0.03^{\mathrm{a}}$ & $1.19 \pm 0.17^{\mathrm{a}}$ \\
\hline Number of senesced leaves & $3.63 \pm 0.62^{\mathrm{a}}$ & $4.23 \pm 0.33^{\mathrm{a}}$ & $0.58 \pm 0.18^{\mathrm{a}}$ & $0.38 \pm 0.08^{\mathrm{a}}$ \\
\hline Stem height change $(\mathrm{cm})$ & $10.3 \pm 0.15^{\mathrm{a}}$ & $9.32 \pm 1.29^{\mathrm{a}}$ & $2.25 \pm 0.39^{\mathrm{a}}$ & $3.14 \pm 0.71^{\mathrm{a}}$ \\
\hline Above-ground biomass ( $\mathrm{g}$ ) & $1.49 \pm 0.13^{\mathrm{a}}$ & $1.68 \pm 0.43^{\mathrm{a}}$ & $0.39 \pm 0.04^{\mathrm{a}}$ & $0.41 \pm 0.03^{\mathrm{a}}$ \\
\hline Below-ground biomass (g) & $1.27 \pm 0.26^{\mathrm{a}}$ & $1.32 \pm 0.22^{\mathrm{a}}$ & $0.14 \pm 0.02^{\mathrm{a}}$ & $0.15 \pm 0.02^{\mathrm{a}}$ \\
\hline
\end{tabular}

${ }^{1}$ Mean values of measured variables with and without E. coqui followed by different superscript letters are significantly different.

*Significant with a Bonferroni adjustment at $\mathrm{P}=0.008$.

herbivorous invertebrate populations and indirect effects on herbivory and plant growth, was fully supported in the small-scale experiment and partially supported in the large-scale experiment. The number of aerial invertebrates was $28 \%$ lower in both experiments when E. coqui were present. In the small-scale experiment, in the presence of E. coqui, the amount of herbivory was approximately $80 \%$ lower and foliage production rates measured as the number of new leaves produced and new leaf area were approximately $80 \%$ higher. In the large-scale experiment, there was also less herbivory in the second 3-mo period in the presence than in the absence of E. coqui. These

(a)

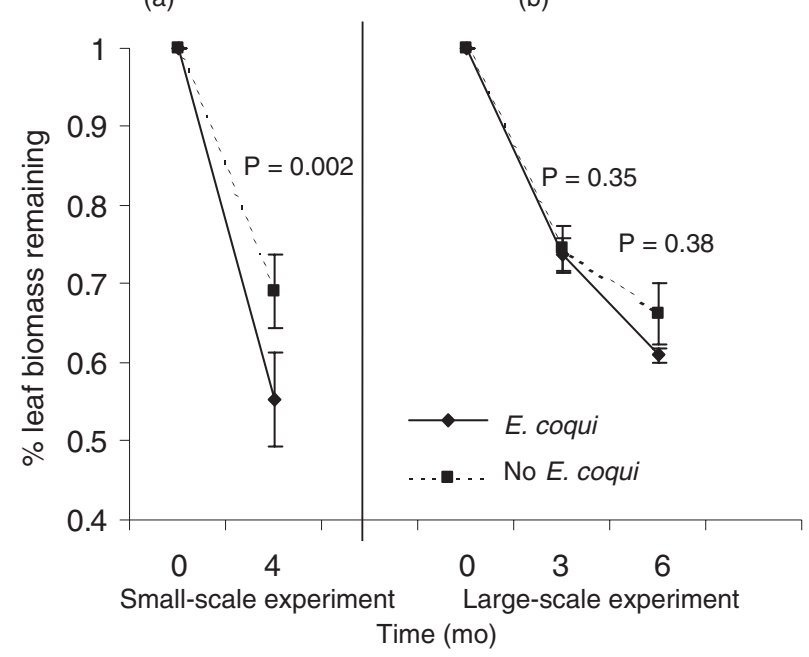

Figure 4. Mean per cent of leaf litter biomass remaining in litterbags $(+\mathrm{SE})$ in enclosures and plots with and without E. coqui in the Bisley Watersheds, Luquillo Experimental Forest, Puerto Rico. (a) Mean per cent biomass remaining after $4 \mathrm{mo}$ in the small-scale experiment. (b) Mean per cent biomass remaining after 3 and 6 mo in the large-scale experiment. results support findings from other studies that have shown that second-order predators can create cascading effects on plant production in tropical systems (Dial \& Roughgarden 1995, Letourneau \& Dyer 1998, Spiller \& Schoener 1990).

Herbivory rates in the study forest are much lower than elsewhere in the tropics (Angulo-Sandoval \& Aide 2000). Comparisons have shown that herbivory rates in LEF, Puerto Rico are much lower than that in Barro Colorado Island, an island without the high densities of insectivores, frogs and lizards, that have been observed in Puerto Rico (Angulo-Sandoval \& Aide 2000). In a previous study conducted in the Bisley Experimental Watersheds in Puerto Rico, it was found that diurnal Anolis control herbivores and plant production (Dial \& Roughgarden 1995). In this study, there were no measurable differences in Anolis density in the frog and frog-free treatments in either the enclosures or plots. Therefore, interactions between $E$. coqui and Anolis do not appear to explain the results of the experiments presented in this paper. Rather, the results of the present study show that the nocturnal frogs also contribute to the low herbivory rates recorded in the study forest. Future studies should be designed to determine if similar results are found in other neotropical island communities that have high insectivore densities.

The second prediction, that $E$. coqui influences the rate at which litter decomposes, was supported in the smallscale experiment. This finding lends support to the hypothesis that top-down forces can influence decomposition rates (Persson et al. 1996, Zheng et al. 1997). The results did not support the first potential explanation for this finding, that $E$. coqui functions as a predator in the detrital food web. Eleutherodactylus coqui did not induce a trophic cascade in the decomposer food web since little or no change was observed in the leaf-litter invertebrate community with E. coqui removal. The only changes 
observed were positive trends between E. coqui and the number of leaf-litter invertebrates (Figure 2). Since invertebrate differences are difficult to detect and these trends were positive for all invertebrate feeding guilds in both experiments, they may represent real differences between the treatments (Robinson 1998).

The increase in leaf-litter decomposition rates in the presence of E. coqui lends support to the second explanation, that $E$. coqui augments the availability of nutrients to soil organisms, which then contributes to decay processes (Gallardo \& Schlesinger 1994, Wardle 1992). We suggest that if $E$. coqui is increasing decomposition rates through nutrient augmentation that it is due to eliminations and excretions, and biomass turnover by E. coqui (Beard et al. 2002). By increasing nutrient availability through this mechanism, other organisms in other systems have been shown to increase microbial communities (Hanlon \& Anderson 1979, Ineson et al. 1982) as well as the abundance of other members of the detritus food chain including larger arthropod predators (Chen \& Wise 1999). Therefore, this explanation also supports the finding that all litter invertebrates generally increased in the presence of E. coqui (Figure 2). Further study is needed on the changes in the microbial community in the presence and absence of E. coqui to support this hypothesis.

In general, in the small-scale experiment, the presence of $E$. coqui was positively associated with increases in plant growth rates (Table 1). We suggest two explanations for this relationship: (1) E. coqui reduces herbivore populations, which in turn reduces herbivory and plant growth loss due to herbivory (Dial \& Roughgarden 1995), and (2) E. coqui increases nutrient availabilities to plants due to its eliminations and excretions, and biomass turnover (Mattson \& Addy 1975, McNaughton et al. 1988). The percentage leaf loss in the experiment due to herbivory was found to be almost negligible (Figure 3) and, therefore, is unlikely to adequately explain plant growth changes. In fact, low levels of folivory more typically stimulate plant growth (compensatory growth) (McNaughton 1979, 1993). Therefore, similar to the changes found in decomposition rates, the plant growth responses to the presence and absence of $E$. coqui in this study are most likely due to the available nutrients released from E. coqui urine, faeces and carcasses.

While our understanding of the role of vertebrate predators in controlling their prey in terrestrial systems is increasing (Hunter 2001b), our understanding of their role in increasing nutrient pools and fluxes through elimination and excretion, and biomass turnover is less developed. Most of the research in terrestrial systems on the influence of consumed nutrients returning to the detrital system in more concentrated and labile forms has focused on herbivore, and in particular insect, and decomposer populations (Coleman \& Hendrix 2000, Hunter 2001a). The results of this study suggest that vertebrate predators can increase both plant productivity and leaf-litter decomposition rates through this mechanism. Future studies designed to determine the importance of vertebrate predator waste material production and population turnover (i.e. carcasses) would greatly add to our knowledge regarding the role of vertebrates in influencing nutrient cycling rates.

\section{A comparison of scales}

Because our study was conducted at two scales, it allowed us the unique opportunity to establish which response variables at each scale were linked to the species (Levin 1992, Schneider 1994, Wiens 1989). Eleutherodactylus coqui effects on most variables, including aerial invertebrates, leaf-litter invertebrates, herbivory and decomposition rates, reflected similar changes in direction and magnitudes at the two different scales in this study (e.g. plant and small forest patch). This is true despite differences in scale, replicate numbers, experimental design (enclosure vs. exclosure), frog densities (post-hurricane vs. natural) and sampling protocols. While the trends were similar in the two experiments for a large majority of the variables measured, significant differences were often found in the small-scale experiment and not the large-scale experiment. The lack of differences between the treatments in the large-scale experiment was either an artifact of the experimental design or real.

Potential explanations for the inability to detect differences between treatments at the larger scale relating to the experimental design include (1) the short temporal duration of the experiment, (2) the different biases of the methods used in the two experiments, and (3) the small number of replicates. It might be expected that if the experiment had been conducted for a longer period of time, more differences between the larger scale treatments would have been detected. However, results were unlikely to change with more time because the processes being monitored either cycle or transform, such as leaf-litter decomposition, at shorter time scales than was used in the experiments (Bloomfield et al. 1993). Different sampling methods used in the two experiments did complicate the analyses. For example, different methods were used to sample similar numbers of invertebrates in the two experiments. The effects of the different sampling methods on the results are difficult to distinguish, and therefore we could not address this issue in this study. This issue should be carefully considered in future studies on the role of species at different scales.

The lack of detectable changes at the larger scale could result from insufficient replication. The human and monetary resources required to conduct the large-scale experiment, with its small number of replications (3 vs. 10 replicates), was approximately five times that of the smallscale experiment. Based on retrospective power analyses, the majority of variables that were not found to be signi- 
ficant in the large-scale experiment had low power $(<0.10)$. The sample size required to detect changes would have been at least an order of magnitude larger than that used in the small-scale experiment. Therefore, we could not determine if the lack of differences found between treatments in the large-scale experiment was 'real'; however, for many variables in this study, the similar direction of the responses at both scales suggests that significant findings at the small-scale are representative of what occurs at the larger scale. Based on the impracticality of increasing the sample size of large-scale experiments, results with low power will often be the only attainable results on terrestrial vertebrate predator effects at large scales. Further studies on the role of terrestrial vertebrate predators at multiple scales are needed to place the results from these experiments into a broader research context.

If there actually were no differences at the large scale, then the smaller scale, which was more representative of the experience of an individual frog, was more effective at detecting species influences on ecosystem processes (Huntly 1995). This supports the hypothesis that some indicators of species effects are scale-dependent at these two scales. Notably, if effects are only detectable at small scales, this does not suggest that the species does not influence the larger scale (Heneghan \& Bolger 1998). Species effects could still be important at the ecosystem level because effects over short and small scales can be important to larger ecosystem processes (Lodge et al. 1994).

\section{Implications}

Studying the role of E. coqui provides some understanding for how E. coqui, and similar species, may affect systems where they have been introduced or are declining. Eleutherodactylus coqui has not experienced significant population declines. In fact, in recent years, the global distribution of E. coqui has been expanding. Eleutherodactylus coqui has been introduced into at least four locations outside of Puerto Rico, and most recently into Hawaii, USA (Kraus et al. 1999). However, other Eleutherodactylus spp. in Puerto Rico have been declining, although no clear understanding of what is causing the declines has been reached (Stallard 2001). This research suggests that in areas where E. coqui has been introduced prey items may decrease and nutrient cycling rates may increase. The reverse trend may be found where Eleutherodactylus spp. have been declining. Studies of community and ecosystem changes where E. coqui has been introduced would greatly add to our understanding of the role of native and non-native vertebrate species in influencing community and ecosystem functions.

\section{ACKNOWLEDGEMENTS}

This research was supported by NSF as part of the LTER Program in the LEF, Puerto Rico, and the Tropical Resources Institute at Yale University. E. Goodwin, A. Kulmatiski, S. McCullough, C. Shipnek and S. VanWart provided field assistance. L. Pyle and C. Wilkinson provided laboratory assistance. A. Kulmatiski, L. Woolbright, R. Wyman and three anonymous reviewers provided useful comments on earlier versions of the manuscript.

\section{LITERATURE CITED}

ANGUlO-SANDOVAL, P. \& AIDE, T. M. 2000. Leaf phenology and leaf damage of saplings in the Luquillo Experimental Forest, Puerto Rico. Biotropica 32:415-422.

BEARD, K. H., VOGT, K. A. \& KULMATISKI, A. 2002. Top-down effects of a terrestrial frog on nutrient dynamics. Oecologia 133:583593.

BLAUSTEIN, A. R. \& KIESECKER, J. M. 2002. Complexity in conservation: lessons from the global decline of amphibian populations. Ecology Letters 5:597-608.

BLOOMFIELD, J., VOGT, K. A. \& VOGT, D. J. 1993. Decay rate and substrate quality of fine roots and foliage of two tropical tree species in the Luquillo Experimental Forest, Puerto Rico. Plant and Soil 150: 233-245.

CALlAWAY, R. M. 1995. Positive interactions among plants. Botanical Review 61:306-349.

CARTER, P. E. \& RYPSTRA, A. L. 1995. Top-down effects in soybean agroecosystems - spider density affects herbivore damage. Oikos $72: 433-439$.

CHEN, B. \& WISE, D. H. 1999. Bottom-up limitation of predaceous arthropods in a detritus-based terrestrial food web. Ecology 80:761772.

COLEMAN, D. \& HENDRIX, P. F. 2000. Invertebrates as webmasters in ecosystems. CABI Publishing, Wallingford, UK. 336 pp.

DAVIDSON, C., SHAFFER, H. B. \& JENNINGS, M. R. 2001. Declines of the California red-legged frog: climate, UV-B, habitat and pesticide hypotheses. Ecological Applications 11:464-479.

DIAL, R. \& ROUGHGARDEN, J. 1995. Experimental removal of insectivores from rain forest canopy: direct and indirect effects. Ecology 76:1821-1834.

EWEL, J. J. \& WHITMORE, J. L. 1973. The ecological life zones of Puerto Rico and the U.S. Virgin Islands. U.S. Forest Service, Institute of Tropical Forestry, Rio Piedras, Puerto Rico.

GALLARDO, A. \& SCHLESINGER, W. H. 1994. Factors limiting microbial biomass in the mineral soil and forest floor of a warmtemperate forest. Soil Biology and Biogeochemistry 26:1409-1415.

GARCIA-MARTINO, A. R., WARNER, G. S., SCATENA, F. N. \& CIVCO, D. L. 1996. Rainfall, runoff and elevation relationships in the Luquillo Mountains of Puerto Rico. Caribbean Journal of Science 32:413-424.

GARRISON, R. W. \& WILLIG, M. R. 1996. Arboreal invertebrates. Pp. 183-246 in Reagan, D. P. \& Waide, R. B. (eds). The food web of a tropical rain forest. University of Chicago Press, Chicago. 
GOLDWASSER, L. \& ROUGHGARDNER, J. 1993. Construction and analysis of a large Caribbean food web. Ecology 74:1216-1233.

GONSER, R. A. \& WOOLBRIGHT, L. L. 1995. Homing behavior of the Puerto Rican frog, Eleutherodactylus coqui. Journal of Herpeto$\log y$ 29:481-484.

GROSS, K. L., WILLIG, M. R., GOUGH, L., INOUYE, R. \& COX, S B. 2000. Patterns of species density and productivity at different spatial scales in herbaceous plant communities. Oikos 89:417-427.

HANLON, R. D. G. \& ANDERSON, J. M. 1979. The effects of Collembola grazing on microbial activity in decomposing leaf litter. Oecologia 38:93-99.

HENEGHAN, L. \& BOLGER, T. 1998. Soil microarthropod contribution to forest ecosystem processes: the importance of observational scale. Plant and Soil 205:113-124.

HUNTER, M. D. 2001a. Insect population dynamics meets ecosystem ecology: effects of herbivory on soil nutrient dynamics. Agricultural and Forest Entomology 3:77-84.

HUNTER, M. D. 2001b. Multiple approaches to estimating the relative importance of top-down and bottom-up forces on insect populations: experiments, life tables, and time series analysis. Basic and Applied Ecology 2:295-309.

HUNTLY, N. 1995. How important are consumer species to ecosystem functioning? Pp. 72-83 in Jones, C. G. \& Lawton, J. H. (eds). Linking species and ecosystems. Chapman and Hall, New York. 432 pp.

INESON, P., LEONARD, M. A. \& ANDERSON, J. M. 1982. Effect of collembolan grazing upon nitrogen and cation leaching from decomposing leaf litter. Soil Biology and Biochemistry 14:601-605.

KAREIVA, P. \& ANDERSON, M. 1988. Spatial aspects of species interactions: the wedding of models and experiments. Pp. 35-50 in Hastings, A. (ed.). Community ecology. Lecture notes in biomathematics 77. Springer-Verlag, Berlin, Germany.

KRAUS, F., CAMPBELL, E. W., ALLISON, A. \& PRATT, T. 1999. Eleutherodactylus frog introductions to Hawaii. Herpetological Review 30:21-25.

LAAKSO, J. \& SETALA, H. 1999. Population- and ecosystem-level effects of predation on microbial-feeding nematodes. Oecologia 120: 279-286.

LETOURNEAU, D. K. \& DYER, L. A. 1998. Experimental test in lowland tropical forest shows top-down effects through four trophic levels. Ecology 79:1678-1687.

LEVIN, S. A. 1992. The problem of pattern and scale in ecology. Ecology 73:1943-1967.

LIPS, K. 1998. Decline of a tropical montane amphibian fauna. Conservation Biology 12:106-117.

LODGE, D. J., MCDOWELL, W. H. \& MCSWINEY, C. P. 1994. The importance of nutrient pulses in tropical forests. Trends in Ecology and Evolution 9:384-387.

MATTSON, W. J. \& ADDY, N. D. 1975. Phytophagous insects as regulators of forest primary production. Science 190:515-522.

MCNAUGHTON, S. J. 1979. Grazing as an optimization process: grassungulate relationships in the Serengeti. American Naturalist 113:601703.

MCNAUGHTON, S. J. 1993. Grasses and grazers, science and management. Ecological Applications 3:17-20.
MCNAUGHTON, S. J., RUESS, R. W. \& SEAGLE, S. W. 1988. Large mammals and process dynamics in African ecosystems. BioScience 38:794-800.

MORAN, M. D. \& HURD, L. E. 1998. A trophic cascade in a diverse arthropod community caused by a generalist arthropod predator. Oecologia 113:126-132.

PERSSON, L., BEnGtSSON, J., MENGE, B. A. \& POWER, M. E. 1996. Productivity and consumer regulation. Pp. 396-434 in Polis, G. A. \& Winemiller, K. O. (eds). Food webs. Integration of patterns and dynamics. Chapman and Hall, New York.

PFEIFFER, W. J. 1996a. Arboreal arachnids. Pp. 247-272 in Reagan, D. P. \& Waide, R. B. (eds). The food web of a tropical rain forest. University of Chicago Press, Chicago.

PFEIFFER, W. J. 1996b. Litter invertebrates. Pp. 137-182 in Reagan, D. P. \& Waide, R. B. (eds). The food web of a tropical rain forest. University of Chicago Press, Chicago.

POUNDS, J. A. \& CRUMP, M. L. 1994. Amphibian declines and climate disturbance: the case of the golden toad and the harlequin frog. Conservation Biology 8:72-85.

ROBINSON, S. K. 1998. Another threat posed by forest fragmentation: reduced food supply. The Auk 115:1-3.

SCHMITZ, O. J., HAMBACK, P. A. \& BECKERMAN, A. P. 2000. Trophic cascades in terrestrial systems: a review of the effects of carnivore removals on plants. American Naturalist 155:141-153.

SCHNEIDER, D. C. 1994. Quantitative ecology: spatial and temporal scaling. Academic Press, San Diego. 395 pp.

SCHOWALTER, T. D. \& GANIO, L. M. 1999. Invertebrate communities in a tropical rain forest canopy in Puerto Rico following Hurricane Hugo. Ecological Entomology 24:191-201.

SPILLER, D. A. \& SCHOENER, T. S. 1990. A terrestrial experiment showing the impact of eliminating top predators on foliage damage. Nature 347:469-471.

STALLARD, R. F. 2001. Possible environmental factors underlying amphibian decline in eastern Puerto Rico: analysis of U.S. government data archives. Conservation Biology 15:943-953.

STEWART, M. M. \& WOOLBRIGHT, L. L. 1996. Amphibians. Pp. 363-398 in Reagan, D. P. \& Waide, R. B. (eds). The food web of a tropical rain forest. University of Chicago Press, Chicago.

STOHLGREN, T. J., BINKELY, D., CHONG, G. W., KALKAN, M. A., SCHELl, L. D., BULL, K. A., OTSUKI, Y., NEWMAN, G., BASKIN, M. \& SON, Y. 1999. Exotic plant species invade hotspots of native plant diversity. Ecological Monographs 69:25-46.

STRONG, A. M., SHERRY, T. W. \& HOLMES, R. T. 2000. Bird predation on herbivorous insects: indirect effects on sugar maple saplings. Oecologia 125:370-379.

SWIFT, M. J., HEALY, I. N. \& ANDERSON, J. M. 1979. Decomposition in terrestrial ecosystems. Studies in ecology. University California Press, Berkeley. 372 pp.

TERBORGH, J. 1988. The big things that run the world - a sequel to E. O. Wilson. Conservation Biology 2:402-403.

TERBORGH, J., LOPEZ, L., NUNEZ, V. P., RAO, M., SHAHABUDDIN, G., ORIHUELA, G., RIVEROS, M., ASCANIO, R., ADLER, G. H., LAMBERT, T. D. \& BALBAS, L. 2001. Ecological meltdown in predator-free forest fragments. Science 294:1923-1926. 
WARDLE, D. A. 1992. A comparative assessment of factors which influence microbial biomass carbon and nitrogen levels in soil. Biological Reviews 67:321-358.

WIENS, J. A. 1989. Spatial scaling in ecology. Functional Ecology 3:385-397.

WOOLBRIGHT, L. L. 1991. The impact of Hurricane Hugo on forest frogs in Puerto Rico. Biotropica 23:462-467.

WOOLBRIGHT, L. L. 1996. Disturbance influences long-term population patterns in the Puerto Rican frog, Eleutherodactylus coqui (Anura: Leptodactylidae). Biotropica 28:493-501.
WOOLBRIGHT, L. L. 1997. Local extinction of anuran amphibians in the Luquillo Experimental Forest of northeastern Puerto Rico. Journal of Herpetology 31:572-576.

WYMAN, R. L. 1998. Experimental assessment of salamanders as predators of detrital food webs: effects on invertebrates, decomposition and the carbon cycle. Biodiversity and Conservation 7:641650 .

ZHENG, D. W., BENGTSSON, J. \& AGREN, G. I. 1997. Soil food webs and ecosystem processes - decomposition in donor-control and Lotka-Volterra systems. American Naturalist 149:125-148. 
